\title{
Heavy Metal Tolerance Among Free-living Fungi Isolated from Soil Receiving Long Term Application of Wastewater
}

\author{
Mohd. Imran ${ }^{1}$, Iqbal Ahmad ${ }^{1}$, Tharcisse Barasubiye ${ }^{2}$, Hussein H. Abulreesh ${ }^{3,4}$ (D), \\ Samreen ${ }^{1}$, Mohammad Khalil Monjed ${ }^{3,4}$ and Khaled Elbanna ${ }^{3,4,5}$
}

${ }^{1}$ Department of Agricultural Microbiology, Faculty of Agricultural Sciences, Aligarh Muslim University, Aligarh 202002, India. ${ }^{2}$ Agriculture and Agri-Food Canada, 960 Carling Ave., Ottawa, Ontario, KIA OC6 Canada. ${ }^{3}$ Department of Biology, Faculty of Applied Science, Umm Al-Qura University, Makkah, Saudi Arabia. ${ }^{4}$ Research Laboratories Center, Faculty of Applied Sciences, Umm Al-Qura University, Makkah, Saudi Arabia. ${ }^{5}$ Department of Agricultural Microbiology, Faculty of Agriculture, Fayoum University, Fayoum, Egypt.

*Correspondence: hhabulreesh@uqu.edu.sa; Tel.: +966555519597

(Received: December 22, 2019; accepted: March 23 2020)

Citation: Mohd. Imran, Iqbal Ahmad, Tharcisse Barasubiye, Hussein H. Abulreesh, Samreen, Mohammad Khalil Monjed and Khaled Elbanna, Heavy Metal Tolerance Among Free-living Fungi Isolated from Soil Receiving Long Term Application of Wastewater, J. Pure Appl. Microbiol., 2020; 14(1):157-170. https://doi.org/10.22207/JPAM.14.1.17

(C) The Author(s) 2020. Open Access. This article is distributed under the terms of the Creative Commons Attribution 4.0 International License which permits unrestricted use, sharing, distribution, and reproduction in any medium, provided you give appropriate credit to the original author(s) and the source, provide a link to the Creative Commons license, and indicate if changes were made. 


\begin{abstract}
In this study fungal profiles of agricultural field soil irrigated with industrial wastewater and sewage containing varying concentrations of heavy metals (Chromium, Nickel, Cobalt, Copper and Cadmium) have been investigated. The impact of long term heavy metal contamination on emergence of heavy metal tolerant soil fungal population, changes in morphological diversity and metal tolerance limits among isolated fungi was studied. The agricultural field soil received long term ( $>20$ years) wastewater application showed metal accumulation compared to the untreated soil. The viable count of soil fungal population from three different agricultural field soil was found in order of $10^{5}$ to $10^{4} \mathrm{CFU} \mathrm{gm}^{-1}$ of soil indicating a normal viable count with little variations. Viable plate count of fungal population on metal amended plates decreased with increasing concentration of tested metals $\left(\mathrm{Cr}^{6+}, \mathrm{Cd}^{++}\right.$. $\mathrm{Cu}^{++}, \mathrm{Co}^{++}$and $\mathrm{Ni}^{++}$) from 100 to $400 \mathrm{\mu gml}^{-1}$. The decrease was higher on cadmium amended plates and lower against Chromium. The control site, which did not receive wastewater application showed relatively less metal tolerant fungal viable count on $\mathrm{Cd}^{++}$and $\mathrm{Ni}^{++}$plates when compared at $100 \mathrm{\mu gml}^{-1}$ as compared to contaminated sites. Similarly, presence of metal tolerant fungal population was also observed from wastewater sample. The common soil fungi isolated and characterized from metal amended plates belong to 18 genera and 15 unidentified species. Occurrence of different fungal genera from site $A$ $B$ and $C$ indicated different patterns of decrease on different metal amended plates with increasing concentration. Among these 73 isolated fungal species a high level of tolerance was recorded to $\mathrm{Cr}^{6+}$ followed by $\mathrm{Cu}^{++}, \mathrm{Co}^{++}$and $\mathrm{Ni}^{++}$while the lowest level of tolerance was for $\mathrm{Cd}^{++}$. The minimum inhibitory concentration (MIC) values of 73 metal tolerant fungal isolates, was ranged from 200 to 2000 $\mathrm{gml}^{-1}$ against one or more heavy metals. The level of tolerance to heavy metals also varied even among the isolates of single genus. Aspergillus was the predominant genus recovered from contaminated soils where the MIC values are highly varied among different isolates of Aspergillus. The current study found that long term release of wastewater has not disturbed the fungal population dynamics in contaminated sites as compared to uncontaminated sites. However, it tends to exert selective pressure on fungal populations of soil, leading to the development of increased level of metal tolerance in fungal species.
\end{abstract}

Keywords: Aspergillus, heavy metals, soil fungi, metal tolerance, MIC, wastewater

\section{INTRODUCTION}

Heavy metal releases to the environment have been increasing continuously and posing significant threat to environment and public health, because of their toxicity, accumulation in soil and food chain ${ }^{1,2}$. Use of wastewater and sewage sludge in agricultural field is a common practice all over the world. Crop irrigation by untreated or poorly treated wastewater/ sewage in developing countries, including India, is considered as widely used practice for waste disposal and nutrient recycling ${ }^{3,4,5}$. The effect of applying sewage solids and wastewater in agricultural lands on soil microbial activities, microbial biomass, respiration and nitrogen mineralization has been widely studied ${ }^{6,7,8}$. Concerns about ecotoxicological impacts of heavy metals and metalloids on soil microorganisms, particularly on quality and quantity of microbial biomass $^{6}$, their effects on soil microbial community composition, structure, and functions are raising ${ }^{8,9}$.
The soil microbial community including heterotrophic free living fungi are the key to the maintaining soil fertility and overall to the soil health. The relationship between fungi and heavy metal contamination in soil is complex and inconsistent in the case of applying sewage sludge to the land ${ }^{2,10}$. Heavy metals at higher concentration are known to cause toxicity to microbial community and their associated activities. However, microorganisms such as fungi have mechanisms to develop resistance and survive even in the presence of toxic metals. The mechanism of metal resistance in fungi includes both its intrinsic ability and genetic background. The common cellular or physiological mechanisms of metal tolerance includes production of organic acids, intracellular or fungal cell wall compounds and metal-binding proteins ${ }^{11}$. Furthermore, the production of metal-binding proteins, active transport, intracellular components, organic and inorganic precipitation, and fungal cell wall 
constituents are the cellular factors influence the tolerance ability of fungi to heavy metals ${ }^{11}$. Most of the studies concerned the impact of heavy metal contamination on distribution of soil bacteria and mycorrhizal fungi 8,12 . However, some limited efforts have been made to evaluate its impact on free-living rhizospheric fungal species, which play a crucial role in degradation of complex organic compounds and nutrient recycling in soi ${ }^{13,14}$. Studies in the past have indicated that wastewater application to the agricultural land can preferentially influence growth of certain group of saprophytic fungi due to change in the soil nutrient status from wastewater application ${ }^{13,15}$. Occurrence of metal tolerant fungi from metal contaminated environment including soil has been reported by many workers ${ }^{16,17,18,19}$. However, the effect of long term application of sewage/ wastewater on soil fungal metal tolerance has not yet systematically investigated in Indian soil. Therefore, the current study aimed to determine how free-living culturable fungal species respond to long term wastewater applications in soil in terms of development of metal tolerant population and level metal resistance in different isolated fungi.

\section{MATERIALS AND METHODS Soil sampling}

Agricultural fields received long term( $>23$ years) application of sewage and untreated industrial effluents mostly from metal lock manufacturing units) as a source for crop irrigation were chosen for soil sampling in the vicinity of Aligarh city at Mathura- road, Aligarh, India. The fields were used to cultivate some food crops like vegetables (Cabbage and Cauliflower), wheat, sugarcane and mustard etc. during the period of sample collection. Randomized sampling of rhizospheric and non rhizospheric soils from the depth of $10-15 \mathrm{~cm}$ was performed by uprooting the plants and collecting rhizospheric soil. Three sites were selected within the chosen field as follows, Site-A (close to wastewater channel), Site-B (relatively far off from wastewater channel), and Site-C (irrigated with groundwater and considered as control (Not treated with wastewater)). Fifty samples were collected randomly from each site to have representative sampling. Later, each ten relatively close distant samples from each site were pooled together to finally obtain five samples per site. Homogenized soil samples were sieved to remove roots and coarse materials. The soil samples were stored in the laboratory at $4{ }^{\circ} \mathrm{C}$ for further analysis if not immediately processed.

Physico chemical and heavy metal analysis of collected soil samples and wastewater

The method described by Vanloon and Lichwa ${ }^{20}$ was adopted for the heavy metal analysis of soil and wastewater treated samples. Briefly, soil samples were converted to ash by overnight treatment at $400{ }^{\circ} \mathrm{C}-500^{\circ} \mathrm{C}$ in a muffled furnace (Tanco, India). The ash sample was cooled and digested with Aquaregia reagent $(2 \mathrm{ml}$ of $65 \%$ $\mathrm{HNO}_{3}+6 \mathrm{ml}$ of $\mathrm{HCl}$ ) on a hot plate until dense fumes evolved and clear solution was obtained. Heavy metal analysis of filtered solution was done by the GBC-932B Plus - Atomic Absorption Spectrometer M/S GBC (Scientific Equipment Pvt. Ltd., Dandenong Victoria, Australia). Similarly, wastewater samples $(25 \mathrm{ml})$ were digested with nitric acid/perchloric acid solution, filtered, and heavy metal content of collected wastewater sample was determined according to standard methods ${ }^{21}$.

\section{Enumeration of soil fungi, morphological} diversity, and identification

The total viable plate count (TVC) of aerobic filamentous fungi was determined by the pour plate technique of serially diluted soil samples up to $10^{-5}$ dilutions. Viable count of fungi was determined on Sabouraud Dextrose Agar (SDA) plates (Hi-Media, Mumbai, India) supplemented with $100 \mathrm{\mu gml}^{-1}$ chloramphenicol to suppress bacterial growth. The plates were allowed to incubate at $28^{\circ} \mathrm{C}$ for seven days.

The isolated fungi were characterized morphologically by cultural, characteristics and microscopic examination. Cultural characteristics such as growth pattern, colour and pigmentation of the recovered fungal colonies have been examined on SDA plates/slants. Fungal structures like septum in fungal hyphae, presence of sexual or asexual forms of isolated strain, shape and arrangement of conidia characteristics of conidiophores were compared with standard manuals used for identification of fungi. Species level identification was achieved in selected genera such as Aspergillus (Aspergillus niger, Aspergillus flavus, Aspergillus terreus, Aspergillus sydowii), 
Rhizopus and Curvularia ) as described earlier 22,23 . Each isolate was given a number and subcultured in duplicate on SDA slants. The cultures were stored at $4^{\circ} \mathrm{C}$ and maintained by repeated sub culturing after 30 days of time interval.

Identification of two selected isolates of Aspergillus by DNA sequencing of Beta-tubulin

Two representative selected isolates of Aspergillus deposited in Canadian Culture Fungal Collection (DAOM239821 and DAOM 2392822) were chosen for molecular identification by DNA sequencing. Pure cultures were grown in $9 \mathrm{~cm}$ polystyrene Petri dishes on potato dextrose agar (PDA, Difco) for 5 days at $22^{\circ} \mathrm{C}$ in the dark. Fungal mycelia were scraped from the surface of the agar using a sterilized scalpel and total genomic DNA was extracted using the DNeasy Plant Mini Kit (QIAGEN, Inc., CA) according to manufacturer's instructions. One $\mu$ l of aliquot was then analyzed on a $1.5 \%$ agarose gel in $0.5 \times$ Tris-borateEDTA buffers to estimate the concentration and quality of the DNA. A primers set (forward: BT2a 5'-GGTAACCAAATCGGTGCTGCTTTC- 3 ' and reverse: Bt2b 5'-ACCCTCAGTGTAGTGACCCTTGGC-3') were used to amplify a portion of coding protein gene beta-tubulin. The PCR amplification was carried out in an Eppendorf cycler, Brinkmann Instruments, Inc. using the no clean method described by Alain-Boule et al., ${ }^{24}$. Briefly each reaction mixture contained $10 \mathrm{ng}$ (usually $1 \mu \mathrm{l}$ ) of diluted template genomic DNA, $1 \times$ of Titanium Taq buffer $(10 \mathrm{x}), 3.5 \mathrm{mM} \mathrm{MgCl}$ included in $10 \mathrm{x}$ buffer, $0.1 \mathrm{mM}$ each of four deoxyribonucleotide triphosphates, $0.08 \mu \mathrm{M}$ of each primer, and 1 unit of Titanium Taq DNA polymerase in a total of 10 $\mu \mathrm{l}$. To amplify beta-tubulin the following cycling program was used. An initial denaturation step of $95^{\circ} \mathrm{C}$ for $3 \mathrm{~min}$ was followed by 40 amplification cycles of denaturation at $95^{\circ} \mathrm{C}$ for $45 \mathrm{~s}$, annealing at $58^{\circ} \mathrm{C}$ for $45 \mathrm{~s}$, and extension at $72^{\circ} \mathrm{C}$ for $90 \mathrm{~s}$. After the 40 cycles were completed, the amplicons were incubated for an additional eight min at $72^{\circ} \mathrm{C}$ for a final extension. A negative control (without DNA template) was used to test for DNA contamination of reagents and reaction mixtures. To estimate the concentration and quality of PCR, $1 \mu$ of amplicon from the PCR reaction was run on a $1.5 \%$ agarose gel with $0.5 \mu \mathrm{g}$ of ethidium bromide per $\mathrm{ml}$ and 0.5 $x$ Tris borate EDTA buffer for 45 min. DNA bands were visualized on a UV trans-illuminator.
Sequencing reaction of beta-tubulin amplicon was performed using the BigDye Terminator V2.0 ready reaction Kit from Applied Biosystems (Forster City, CA) and $0.5 x$ reactions. An estimated 10-20 ng of each amplicon was sequenced in both directions using the same primers described for PCR above. Sequencing reactions were analyzed with the ABI 3100-Avant automated sequencer (Applied Biosystems/Hitachi). Contigs were assembled and sequences were edited using SeqMan version 6.1 (DNASTAR, Madison, WI). The sequences of Aspergillus niger and $A$. sydowii were deposited in GenBank respectively under accession numbers EU907906 and EU907905.They were used to establish identity of the isolates based on sequences similarity in GenBank using the BLASTn program for nucleotide-nucleotide analysis (version 2.0, National Center for Biotechnology Information (NCBI), United States National Institutes of Health, Bethesda, MD).

\section{Determination of metal tolerant fungi in soil and wastewater samples}

To assess the metal tolerant fungi within the collected soil samples from three sites, stock solutions of chloride salts of metals like copper, cadmium, nickel, cobalt, and potassium dichromate $\left(\mathrm{K}_{2} \mathrm{Cr}_{2} \mathrm{O}_{7}\right)$ were dissolved individually in double distilled water as these stocks represent a heavy metals forms of $\mathrm{Cd}^{++}, \mathrm{Ni}^{++}, \mathrm{Cu}^{++}, \mathrm{Co}^{++}$and $\mathrm{Cr}^{6+}$, respectively. Different sets of SDA plates incorporated with different concentrations (50, 100,200 , and $400 \mathrm{\mu gml}^{-1}$ ) of freshly prepared heavy metals stock solution were prepared individually. An aliquot of $100 \mu$ of 1:10 diluted soil samples in sterile distilled water was spread onto SDA plates (three replicates) incorporated with above concentration of individual metal.. SDA plates without metal were also included as a control. The total viable count of developed fungal colonies was recorded as CFU per gram of soil after 3-7 days incubation at $28^{\circ} \mathrm{C}$. The fungal colonies recovered with distinct phenotype on SDA plates were identified. Change in the phenotypic diversity of fungi was also recorded at varying concentrations of heavy metals.

Likewise, metal tolerant fungi in collected samples of wastewater were also determined by serial dilution of wastewater up to $10^{-4}$ dilution. An aliquot of $100 \mu$ l of each dilution was spread on metal amended and metal-free plates, as 
described above and characterized as described earlier. Metal tolerant fungi from three sampling sites (wastewater irrigated and non-wastewater irrigated) were isolated from one or other metal amended $\left(100 \mu \mathrm{g} \mathrm{ml}^{-1}\right)$ plates and purified after repeated streaking. Each isolate after tentative identification as described above is given an isolate number. The purified isolates were preserved at 4 ${ }^{\circ} \mathrm{C}$ in agar slants by repeated sub culturing.

Evaluation of minimum inhibitory concentration (MIC) of heavy metals against isolated fungi

Heavy metal resistance levels among soil fungi isolated from metal amended plates (100 $\mu \mathrm{g} \mathrm{ml}^{-1}$ ) were assessed by determining minimum inhibitory concentration (MIC) of individual metal against test fungi by spot plate method ${ }^{23}$. Briefly, different sets of SDA incorporated with varying concentrations of heavy metals, ranged from 100 to $2000 \mathrm{\mu g} \mathrm{ml}^{-1}$ was prepared as mentioned previously. An inoculum of examined fungal spore

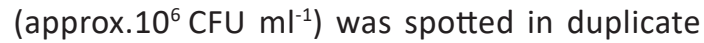
on metal amended and control plates (plates containing no metal). The plates were incubated at $28{ }^{\circ} \mathrm{C}$ for seven days to be examined for the growth of fungi on the spotted area. MIC was defined as the lowest concentration of metal that inhibited the visible growth of inoculated fungi and expressed in $\mu \mathrm{g} \mathrm{ml} \mathrm{m}^{-1}$.

\section{RESULTS}

Heavy metal content of wastewater and soil

Heavy metal analysis of wastewater

Table 1a. Heavy metal analysis of wastewater and wastewater irrigated soils

\begin{tabular}{|c|c|c|c|c|c|}
\hline \multirow[t]{2}{*}{ Designated sites } & \multicolumn{5}{|c|}{ 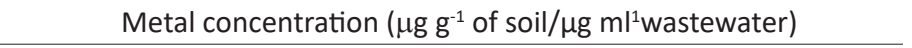 } \\
\hline & $\mathrm{Cr}^{6+}$ & $\mathrm{Cd}^{++}$ & $\mathrm{Ni}^{++}$ & $\mathrm{Cu}^{++}$ & $\mathrm{Co}^{++}$ \\
\hline Soil (Site-A*) & $121.5 \pm 0.58$ & $2.8 \pm 0.29$ & $125 \pm 0.63$ & $7.2 \pm 0.25$ & $26.7 \pm 0.09$ \\
\hline Soil (Site-B*) & $119.2 \pm 0.51$ & $2.7 \pm 0.18$ & $136 \pm 0.71$ & $6.8 \pm 0.22$ & $23.8 \pm 0.08$ \\
\hline Soil $\left(\right.$ Site- $\left.C^{\dagger}\right)$ & $98.1 \pm 0.48$ & $1.51 \pm 0.07$ & $105 \pm 0.45$ & $5.9 \pm 0.19$ & $5.4 \pm 0.13$ \\
\hline $\mathrm{P} \ddagger$ & $<0.05$ & NS & $<0.05$ & NS & $<0.05$ \\
\hline Wastewater & $79.5 \pm 0.33$ & $1.19 \pm 0.04$ & $78.50 \pm 0.38$ & $3.6 \pm 0.10$ & $15.7 \pm 0.69$ \\
\hline
\end{tabular}

\pm indicates SD of three replicates;

* indicates Wastewater irrigated agricultural fields soil

${ }^{+}$indicates non wastewater irrigated agricultural fields soil.

$\ddagger \mathrm{P}$ is value from $\mathrm{T}$ test comparing means of two independent samples, we compared metal contents in site $\mathrm{A}$ and site $\mathrm{C}$.

NS, not significant

Table 1b. Physico-chemical characteristics of Aligarh soil. under study revealed the presence of $\mathrm{Cr}^{6+}(79.5 \mu \mathrm{g}$

\begin{tabular}{lll}
\hline Characteristics & $\begin{array}{l}\text { Wastewater } \\
\text { Soil (Sites A \& B) } \\
\text { irrigated }\end{array}$ & $\begin{array}{l}\text { Non wastewater } \\
\text { irrigated soil } \\
\text { (Site-C) }\end{array}$ \\
\hline $\mathrm{pH}$ & 8.1 & 8.7 \\
E.C.(ms/cm) & 0.27 & 0.25 \\
Sand (\%) & 62.76 & 62.66 \\
Silt (\%) & 14.0 & 13.25 \\
Clay (\%) & 23.20 & 23.15 \\
Soil class & Sandy clay loam & Sandy clay loam \\
Type & Alluvial & Alluvial \\
Water holding & & \\
capacity & $0.44 \mathrm{ml} / \mathrm{g}$ & $0.43 \mathrm{ml} / \mathrm{g}$ \\
C.E.C. & $15.6(\mathrm{C} \mathrm{mol} / \mathrm{kg})$ & $15.1(\mathrm{C} \mathrm{mol} / \mathrm{kg})$ \\
A.E.C. & $6.8(\mathrm{C} \mathrm{mol} / \mathrm{kg})$ & $6.6(\mathrm{C} \mathrm{mol} / \mathrm{kg})$ \\
Kjeldal N & $0.075 \mathrm{~g} / \mathrm{kg}$ & $0.073 \mathrm{~g} / \mathrm{kg}$ \\
Olcen P & $16 \mathrm{mg} / \mathrm{kg}$ & $15.22 \mathrm{mg} / \mathrm{kg}$ \\
Organic C (\%) & 0.40 & 0.38
\end{tabular}
$\left.\mathrm{ml}^{-1}\right)$ followed by $\mathrm{Ni}^{++}\left(78.5 \mu \mathrm{g} \mathrm{ml}^{-1}\right), \mathrm{Co}^{++}(15.7 \mu \mathrm{g}$ $\left.\mathrm{ml}^{-1}\right), \mathrm{Cu}^{++}\left(3.6 \mu \mathrm{g} \mathrm{ml}^{-1}\right)$, and least to $\mathrm{Cd}^{++}(1.19 \mu \mathrm{g}$ $\mathrm{ml}^{-1}$ ). Agricultural fields at sites-A and $B$ irrigated with wastewater exhibited almost similar heavy metal content. However $\mathrm{Ni}^{++}, \mathrm{Cr}^{6+}$ and $\mathrm{Co}^{++}(P<0.05$, $T$ test) content was relatively more in treated soil compared to soil from control fields (site-C) as depicted in Table 1a. The physicochemical characteristics of soil from all three sampling sites indicated almost similar characteristics as shown in Table1b.

Occurrence of fungal population in soil and wastewater sample

Total viable count (TVC) of aerobic fungi recovered from rhizospheric and non-rhizospheric soil treated with wastewater is presented in Table 2 . In general the total viable count of fungi in 
rhizospheric soil was almost 10 fold higher than non-rhizospheric soil. Fungal population density of soil ranged from $2.5 \times 10^{5}$ to $3.25 \times 10^{5}, 2.1 \times 10^{5}$ to $2.9 \times 10^{5}$ and $6.8 \times 10^{5}$ to $7.9 \times 10^{5} \mathrm{CFU} \mathrm{g}^{-1}$ soil in the site-A, B and site-C respectively. The Kruskal-Wallis test showed that TVC of fungi in soil collected from contaminated sites with wastewater (sites-A and $B$ ) was significantly lower $(p<0.05)$ than what recorded for uncontaminated soil (site-C).

Table 2. Fungal viable counts in soil receiving long term application of wastewater in rhizosphere and bulk soils

\begin{tabular}{|c|c|c|c|c|c|}
\hline \multirow[b]{2}{*}{$\begin{array}{l}\text { Nature } \\
\text { of site }\end{array}$} & \multirow[b]{2}{*}{$\begin{array}{l}\text { Soil } \\
\text { sampling } \\
\text { site }\end{array}$} & \multirow[b]{2}{*}{ Crops } & \multirow[b]{2}{*}{$\begin{array}{l}\text { Composite Soil } \\
\text { Samples }\end{array}$} & \multicolumn{2}{|c|}{ Viable count (CFU g ${ }^{-1}$ of soil) } \\
\hline & & & & $\begin{array}{l}\text { Rhizospheric soil } \\
\text { Filamentous fungi } \\
\left(\times 10^{5}\right)\end{array}$ & $\begin{array}{l}\text { Non rhizospheric soil } \\
\text { Filamentous fungi } \\
\left(\times 10^{4}\right)\end{array}$ \\
\hline \multirow{7}{*}{$\begin{array}{l}\text { Waste } \\
\text { water } \\
\text { irrigated } \\
\text { soil }\end{array}$} & \multirow[t]{5}{*}{ Site-A } & Wheat & $A-1$ & $2.8 \pm 0.25$ & $3.2 \pm 0.21$ \\
\hline & & Green gram & $A-2$ & $3.25 \pm 0.22$ & $3.5 \pm 0.26$ \\
\hline & & Cabbage & $A-3$ & $3.1 \pm 0.30$ & $2.5 \pm 0.18$ \\
\hline & & Cauliflower & $A-4$ & $2.7 \pm 0.23$ & $2.2 \pm 0.15$ \\
\hline & & Chickpea & $A-5$ & $2.5 \pm 0.20$ & $1.9 \pm 0.11$ \\
\hline & \multirow[t]{5}{*}{ Site-B } & Sugarcane & B-1 & $2.6 \pm 0.18$ & $2.3 \pm 0.15$ \\
\hline & & Chickpea & B-2 & $2.8 \pm 0.15$ & $3.0 \pm 0.29$ \\
\hline \multirow{9}{*}{$\begin{array}{l}\text { Non waste } \\
\text { water } \\
\text { irrigated } \\
\text { soil }\end{array}$} & & Wheat & B-3 & $2.1 \pm 0.17$ & $2.3 \pm 0.20$ \\
\hline & & Brinjal & B-4 & $2.3 \pm 0.25$ & $2.6 \pm 0.19$ \\
\hline & & Cabbage & B-5 & $2.9 \pm 0.26$ & $3.2 \pm 0.24$ \\
\hline & \multirow[t]{6}{*}{ Site-C } & Mustard & C-1 & $7.6 \pm 0.65$ & $8.1 \pm 0.55$ \\
\hline & & Chickpea & $\mathrm{C}-2$ & $7.3 \pm 0.70$ & $6.6 \pm 0.49$ \\
\hline & & Wheat & $\mathrm{C}-3$ & $7.9 \pm 0.69$ & $8.6 \pm 0.50$ \\
\hline & & Sugarcane & $C-4$ & $7.1 \pm 0.70$ & $6.5 \pm 0.48$ \\
\hline & & Green gram & $C-5$ & $6.8 \pm 0.60$ & $7.5 \pm 0.57$ \\
\hline & & $P$ & & $<0.05$ & $<0.05$ \\
\hline
\end{tabular}

\pm indicates SD of three replicates

Pis Kruskal-Wallis testing the null hypothesis that fungal total viable counts do not differ in soil irrigated and nonirrigated with wastewater.

\section{Metal tolerant fungal populations in soil} Occurrence of metal tolerant fungal population developed upon the metal amended plates recovered from both contaminated and uncontaminated soils at varying concentrations of metals are presented in Table 3. Generally, the total number of recovered CFUs from SDA plates incorporated with $100 \mathrm{mg} \mathrm{ml}^{-1}$ of examined metals that inoculated with soils collected from all sites $(A, B$, and $C)$ and wastewater were lower than the total number of recovered CFUs from control SDA plates contained no metals. At three metal amended concentrations (100, 200 and $400 \mu \mathrm{g} \mathrm{ml}^{-1}$ ) of plates the total viable plate count decreases with increasing concentration of metal. The sampling site-A showed the fungal population tolerant to chromium was $1.8 \times 10^{5} \mathrm{CFU} \mathrm{gm}^{-1}$ at 100 $\mu \mathrm{g} \mathrm{ml}{ }^{-1}$ followed by $\mathrm{Ni}^{++}$tolerant population (1.46 $\left.\mathrm{x} 10^{5} \mathrm{CFU}\right), \mathrm{Cu}^{++}\left(2.8 \times 10^{4}\right), \mathrm{Cd}^{++}\left(2.4 \times 10^{4}\right)$ and $\mathrm{Co}^{++}$
(3.7 $\left.\times 10^{3} \mathrm{CFU}\right)$.These CFU counts are comparatively low with the CFU obtained on control plates which was $2.9 \times 10^{5} \mathrm{CFU} \mathrm{gm}^{-1}$ of soil. Site-B metal tolerant fungal population is almost similar to site-A as depicted from Table 3. Analysis from the control site (Site-C) showed, however, that the fungal population tolerant to chromium was significantly lower ( $p<0.05$, T-test) to Site-A (treated soils). This was also observed when cobalt was present $\left(p<0.01, T\right.$-test) at the concentration of $400 \mu \mathrm{g} \mathrm{ml}^{-1}$ for both metals (Table 3). Moreover, metal tolerant fungal populations against at the concentration of $400 \mu \mathrm{g} \mathrm{ml}^{-1}$ varied against $\mathrm{Cu}^{++}, \mathrm{Cd}^{++}$and $\mathrm{Ni}^{++}$among three sites (Table 3).

Interestingly, cadmium and nickel tolerant fungal populations were less at the control site, compared to other metals. On the other hand, $\mathrm{Cd}^{++}$and $\mathrm{Ni}^{++}$tolerant fungi from the treated sites ( $A$ and $B$ ) were high in number as compared to 
Table 3. Viable count of metal tolerant fungal population of soil at varying concentrations of heavy metals

\begin{tabular}{|c|c|c|c|c|}
\hline \multirow[t]{3}{*}{ Metal } & \multirow{3}{*}{$\begin{array}{l}\text { Metal } \\
\text { Concentration } \\
(\mu \mathrm{g} / \mathrm{ml})\end{array}$} & \multicolumn{3}{|c|}{$\mathrm{CFUg}^{-1}$ of soil (mean value of three replicates) } \\
\hline & & \multicolumn{2}{|c|}{$\begin{array}{l}\text { Wastewater } \\
\text { irrigated soil }\end{array}$} & \multirow{2}{*}{$\begin{array}{l}\text { Non-wastewater } \\
\text { irrigated soil } \\
\text { Site-C }+\times 10^{4}\end{array}$} \\
\hline & & Site-A $+\times 10^{4}$ & Site-B $\times 10^{4}$ & \\
\hline Control & No Metal & $29 \pm 0.15 \times$ & $27 \pm 0.22$ & $78 \pm 0.51$ \\
\hline \multirow[t]{4}{*}{$\mathrm{Cr}$} & 100 & $18 \pm 0.1$ & $17.3 \pm 0.15$ & $64 \pm 0.45$ \\
\hline & 200 & $15.8 \pm 0.1$ & $9.5 \pm 0.8$ & $85 \pm 0.61$ \\
\hline & 400 & $8.0 \pm 0.7 \times 10^{4}$ & $7.6 \pm 0.6$ & $6.2 \pm 0.5$ \\
\hline & $p^{+}$ & $<0.05$ & & \\
\hline \multirow[t]{4}{*}{$\mathrm{Cd}$} & 100 & $2.4 \pm 0.2$ & $1.7 \pm 0.13$ & $0.35 \pm 0.24$ \\
\hline & 200 & $1.4 \pm 0.1$ & $1.5 \pm 0.1$ & $0.21 \pm 0.14$ \\
\hline & 400 & $0.029 \pm 0.16$ & $0.80 \pm 0.8$ & $0.041 \pm 0.25$ \\
\hline & $p^{+}$ & $<0.01$ & & \\
\hline \multirow[t]{4}{*}{$\mathrm{Ni}$} & 100 & $14.6 \pm 0.12$ & $15.7 \pm 0.12$ & $0.55 \pm 0.35$ \\
\hline & 200 & $2.3 \pm 0.18$ & $2.9 \pm 0.27$ & $0.35 \pm 0.26$ \\
\hline & 400 & $0.24 \pm 0.21$ & $0.22 \pm 0.2$ & $0.081 \pm 0.52$ \\
\hline & $p^{+}$ & $<0.01$ & & \\
\hline \multirow[t]{4}{*}{$\mathrm{Cu}$} & 100 & $2.8 \pm 0.25$ & $2.7 \pm 0.19$ & $2.0 \pm 0.14$ \\
\hline & 200 & $0.24 \pm 0.19$ & $2.2 \pm 0.25$ & $0.62 \pm 0.49$ \\
\hline & 400 & $0.20 \pm 0.16$ & $0.25 \pm 0.27$ & $0.35 \pm 0.28$ \\
\hline & $p^{+}$ & $<0.01$ & & \\
\hline \multirow[t]{4}{*}{ Co } & 100 & $0.37 \pm 0.28$ & $1.9 \pm 0.2$ & $0.45 \pm 0.31$ \\
\hline & 200 & $0.19 \pm 0.14$ & $0.54 \pm 0.52$ & $0.27 \pm 0.21$ \\
\hline & 400 & $0.080 \pm 0.6$ & $0.21 \pm 0.23$ & $0.18 \pm 0.20$ \\
\hline & $p^{+}$ & $<0.01$ & & \\
\hline
\end{tabular}

\pm indicates SD of three replicates

$p+$ is the $p$ value from the Wilcoxon test for matched pairs ( $T$ test) comparing the metal tolerant fungal populations in contaminated site-A and non-contaminated site-C when $400 \mu \mathrm{g} \mathrm{ml}^{-1}$ of metal was used.

the control site (Table 3). Wastewater analysis demonstrated the presence of metal tolerant fungal species at $100 \mu \mathrm{g} \mathrm{ml}^{-1}$ concentration against all tested metals at the frequency of $2.1 \times 10^{4} \mathrm{CFU}$

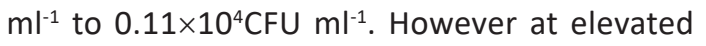
concentration of heavy metals $\left(400 \mu \mathrm{g} \mathrm{ml}^{-1}\right)$, the levels of fungal populations sharply decreased from $1.35 \times 10^{4} \mathrm{CFU} \mathrm{ml}^{-1}$ to nil (Table 4).

Effects of heavy metal concentration on fungal diversity

Occurrence of different species of fungi on control SDA plates (contained no heavy metal) from the three sites (A, B and $C)$ revealed 18 different genera and certain unidentified isolates of fungi as indicated in Fig. 1. The predominant identified fungi belong to genera Aspergillus, followed by Curvularia, Mycelia sterillia, Penicillium, Rhizopus, Alternaria, Mucor, Microsporium, Monotospora, Monilia, Trichoderma, Trichophyton, Chlamydospora, Fusarium, Hormodendrum,
Nigrospora, , Trichothecium, Verticillium and some unidentified fungal genera. Among Aspergillus isolates $A$. niger, A. flavus, $A$. sydowii and $A$. terrues are most common species represented by $4,3,3$ and 2 isolates respectively. Common isolates of Curvularia and Rhizopus was identified as Curvularia clavata and Rhizopus oryzae .

Two Aspergillus isolates (Asp-07 and Asp 01) were chosen for the molecular identification to confirm their species level identity. A BLAST search of the NCBI database revealed $A$. niger as the closest match to our isolate DAOM 239822. Using the BLASTn program, the four most significant sequences (accession numbers NW001594179, AY820002, AY585536, AY820005 with more than $99.4 \%$ similarity to our strain were considered to confirm identity. A total score of 1059 for the top four sequences was obtained and the expectation E value was 0.0 . 


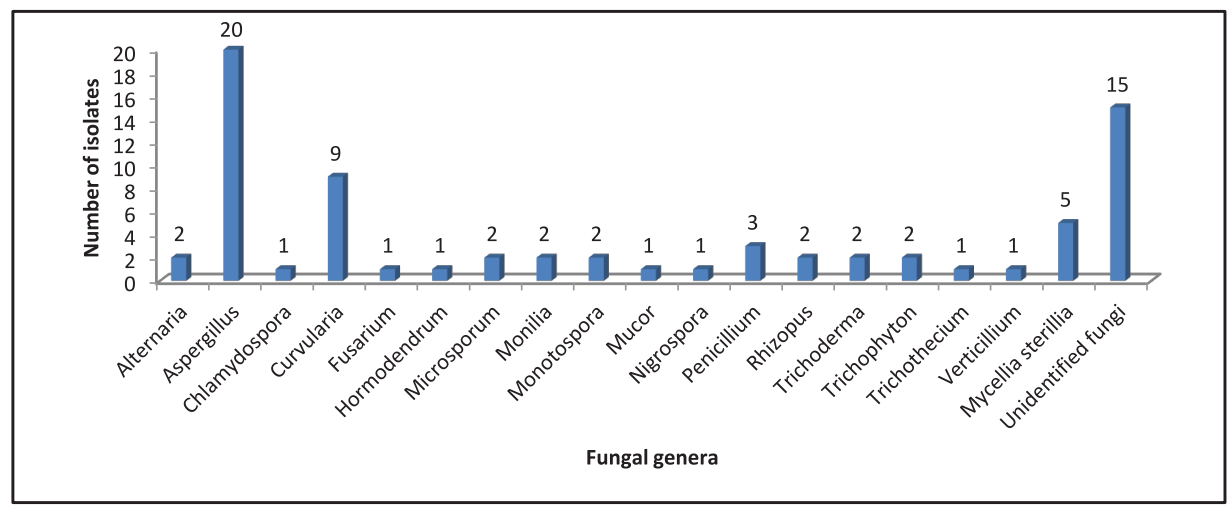

Fig. 1. The fungal genera isolated from soil samples of all three sites

By the same analysis a group of four sequences (accession numbers (EF652274, EF652297, EF652275, EF428373) obtained from A. sydowii and having a total score greater than 702 and $E$ value of 0.0 was considered to establish identity of isolate DAOM239822 of $A$. sydowii. The next closet species was $A$. versicolor with a total score of 626 and expectation E value of 1.7e-176.

The occurrence of different colonial diversity on metal amended plates decreased as the concentration of metal in the medium increased in comparison with the control plate. A decrease in fungal diversity on metals amended plates from treated soil samples is depicted in Fig. 2 ( $a, b$ and c). This decrease in the diversity on chromium supplemented plates was lower than other metals and higher in plates supplemented with $\mathrm{Co}^{++}$and $\mathrm{Cu}^{++}$, respectively. The control site-C (untreated soil) showed relatively less diversity of metal-tolerance fungal species compared to treated soils (sites A and B) as shown in Fig. 2a,b, and $c$. For example, there were 13 different fungal species detected in the soil of site-C compared to 8 fungal species on plate augmented with chromium at $100 \mathrm{~g} \mathrm{ml}^{-1}$ from soil site-A. Similarly, on plates supplemented with $200 \mathrm{\mu g} \mathrm{ml}^{-1}$ of $\mathrm{Cu}^{++}, 9$ different fungal species were detected from the soil of site- $\mathrm{A}$, while on the same metal concentration only 6 different fungal species were detected in control site-C. It is worth mentioning that Aspergillus $\mathrm{sp}$. was the only genus to grow on every plate supplemented with different concentrations of all heavy metals from all three types of soil.

Tolerance level among isolated fungal genera against heavy metals

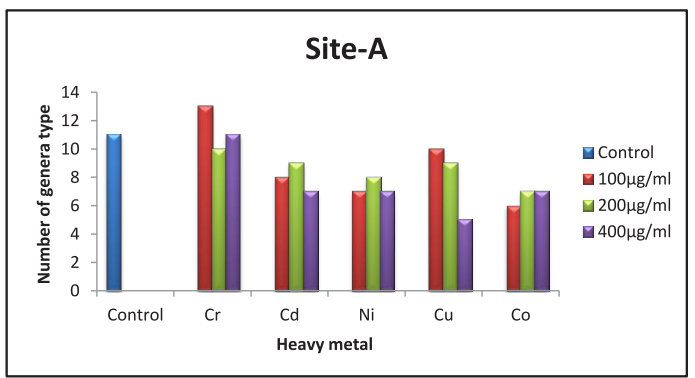

Fig. 2a. Diversity of soil fungal genera at different concentration of heavy metals at site-A.

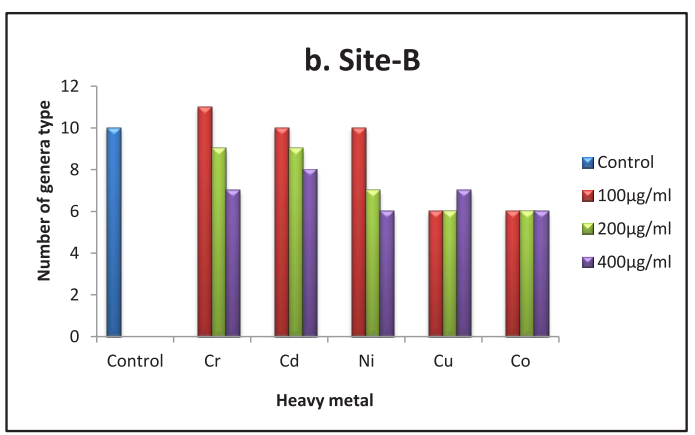

Fig. 2b. Diversity of soil fungal genera at different concentration of heavy metals from site-B.

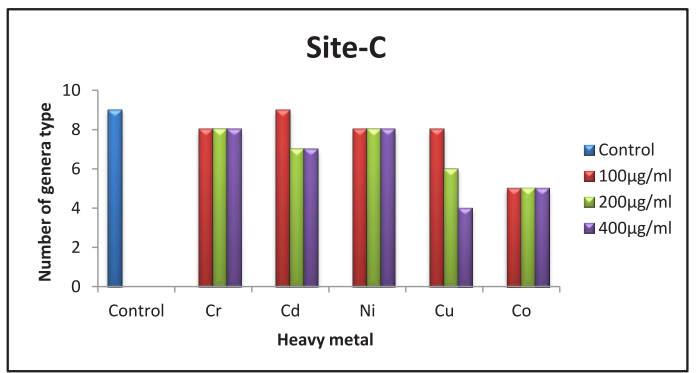

Fig. 2c. Diversity of soil fungal genera at different concentration of heavy metals from site-C. 
Table 4. Viable count of metal tolerant fungal population in wastewater at varying concentrations of heavy metals

\begin{tabular}{lll}
\hline Metal & $\begin{array}{l}\text { Metal } \\
\text { Conc. } \\
(\mu \mathrm{g} / \mathrm{ml})\end{array}$ & $\begin{array}{l}\text { CFU } \mathrm{ml}^{-1} \text { of water (mean } \\
\text { value of three replicates) } \\
\text { Fungi } \times 10^{4}\end{array}$ \\
\hline Control & No Metal & $3.5 \pm 0.32$ \\
$\mathrm{Cr}$ & 100 & $2.1 \pm 0.2$ \\
& 200 & $1.85 \pm 0.12$ \\
& 400 & $1.35 \pm 0.1$ \\
$\mathrm{Cd}$ & 100 & $0.11 \pm 0.15$ \\
& 200 & Nil \\
$\mathrm{Ni}$ & 400 & Nil \\
& 100 & $1.9 \pm 0.14$ \\
& 200 & $0.45 \pm 0.35$ \\
$\mathrm{Cu}$ & 400 & $0.42 \pm 0.4$ \\
& 100 & $1.26 \pm 0.17$ \\
& 200 & $0.42 \pm 0.39$ \\
$\mathrm{Co}$ & 400 & $0.26 \pm 0.25$ \\
& 100 & $0.62 \pm 0.6$ \\
& 200 & $0.22 \pm 0.22$ \\
& 400 & $0.21 \pm 0.25$ \\
\hline
\end{tabular}

\pm indicates SD of three replicates

A total of seventy-three filamentous fungal isolates, belonging to 18 different genera beside 15 unidentified isolates recovered from SDA plates incorporated individually with $100 \mathrm{\mu g} \mathrm{ml}^{-1}$ of individual metal were tested for tolerance limits in term of MIC value. The MIC obtained showed high level of tolerance to these metals among isolated fungi such as Aspergillus isolates followed by Penicillium, Rhizopus, Curvularia, Trichophyton, Trichoderma, and Mycelia sterillia. Similarly other fungal genera, as well as unidentified isolates, could also demonstrate an increased level of tolerance (MIC $\geq 1600 \mathrm{~g} \mathrm{ml}^{-1}$ ) against heavy metals as depicted in Table 5 and Fig. 3.

Similarly, among 20 different isolates of Aspergillus mainly belonging to $A$. niger, A. flavus, $A$. sydowii and $A$. terreus and other unconfirmed species showed different levels of tolerance against tested metals. Variations in the MIC values of metal against Aspergillus isolates is shown in Fig 4. Statistical differences were observed in terms of the level of tolerance among Aspergillus isolates towards the tested metals ( $p<0.01$, Kruskal-Wallis test). Low MIC values was observed against $\mathrm{Cd}^{++}$, where the values are less than $900 \mu \mathrm{g} \mathrm{ml}^{-1}$ for $55 \%$ of the isolated species, On another hand, 75 $\%$ of identified Aspergillus species showed high tolerance against $\mathrm{Co}^{++}$, where MIC values ranged from $1000 \mu \mathrm{g} \mathrm{ml}^{-1}$ up to $2000 \mu \mathrm{g} \mathrm{ml}^{-1}$ (Table 6). The Mann-Whitney ( $U$ test), showed significant difference $(p<0.05)$ when the MIC values of the 20 Aspergillus species against $\mathrm{Cd}^{++}$(low tolerance) and $\mathrm{Co}^{++}$(high tolerance) were compared (Table 6).

Table 5. Minimum inhibitory concentration (MIC) range of heavy metals against 73 soil fungal isolates

\begin{tabular}{|c|c|c|c|c|c|c|}
\hline \multirow[t]{2}{*}{ Fungal genera } & \multirow[t]{2}{*}{ No. of isolates } & \multicolumn{4}{|c|}{$\operatorname{MIC}\left(\mu \mathrm{gml}^{-1}\right)$} & \multirow[b]{2}{*}{ Co } \\
\hline & & $\mathrm{Cr}$ & $\mathrm{Cd}$ & $\mathrm{Ni}$ & $\mathrm{Cu}$ & \\
\hline Alternaria & 2 & $400-800$ & $400-800$ & $400-1200$ & 800 & $400-800$ \\
\hline Aspergillus & 20 & $200-2000$ & $200-800$ & $200-1600$ & $200-1200$ & $400-2000$ \\
\hline Chlamydospora & 1 & 1200 & 200 & 800 & 400 & 1200 \\
\hline Curvularia & 9 & $400-2000$ & $400-1200$ & $800-1600$ & $800-1200$ & $800-2000$ \\
\hline Fusarium & 1 & 1200 & 800 & 1600 & 1200 & 1200 \\
\hline Hormodendrum & 1 & 400 & 200 & 800 & 800 & 800 \\
\hline Microsporum & 2 & $800-1200$ & $200-800$ & 800 & 800 & $1200-1600$ \\
\hline Monotospora & 2 & $400-1200$ & $400-800$ & 800 & 800 & $800-1200$ \\
\hline Monilia & 2 & $1200-2000$ & $200-800$ & $1200-1600$ & $800-1200$ & $1600-2000$ \\
\hline Mucor & 1 & 800 & 400 & 1200 & 800 & 800 \\
\hline Nigrospora & 1 & 400 & 400 & 800 & 800 & 1200 \\
\hline Penicillium & 3 & $400-1200$ & $200-800$ & $800-1600$ & $800-1600$ & $800-2000$ \\
\hline Rhizopus & 2 & $1200-1600$ & 1200 & $1200-1600$ & $800-1200$ & $800-2000$ \\
\hline Trichophyton & 2 & $400-2000$ & $400-800$ & $800-1600$ & $800-1200$ & $1200-2000$ \\
\hline Trichoderma & 2 & $800-2000$ & $400-800$ & $800-1200$ & 800 & 2000 \\
\hline Trichothecium & 1 & 800 & 400 & 1600 & 1200 & 1200 \\
\hline Verticillium & 1 & 400 & 200 & 1200 & 800 & 1200 \\
\hline Mycelia sterillia & 5 & $1200-1600$ & $200-800$ & $800-1200$ & $800-1200$ & 1600 \\
\hline Unidentified & 15 & $400-1600$ & $200-1200$ & $400-2000$ & $400-2000$ & $800-2000$ \\
\hline
\end{tabular}




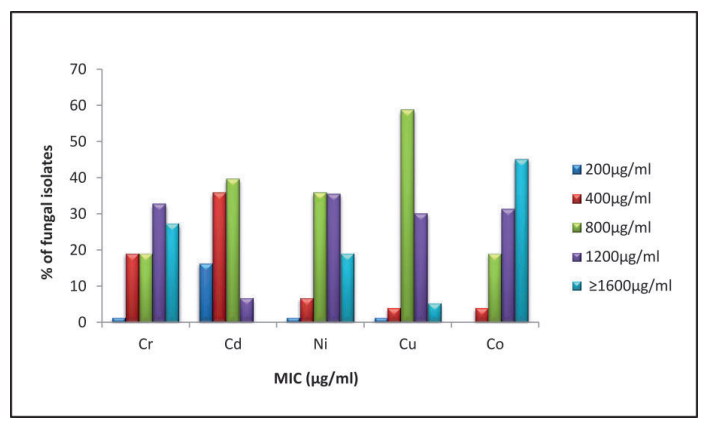

Fig. 3. Heavy metal tolerance level among 73 soil fungal isolates.

Table 6. Minimum inhibitory concentration (MIC) of heavy metals against different isolates of Aspergillus

\begin{tabular}{lccccc}
\hline \multirow{2}{*}{$\mathrm{MIC}\left(\mu \mathrm{g} \mathrm{ml}^{-1}\right)$} & \multicolumn{5}{c}{$\begin{array}{c}\text { Number of } \\
\text { with MIC against hergillus isolates }\end{array}$} \\
\cline { 2 - 6 } & $\mathrm{Cr}^{6+}$ & $\mathrm{Cd}^{+2}$ & $\mathrm{Ni}^{+2}$ & $\mathrm{Cu}^{+2}$ & $\mathrm{Co}^{+2}$ \\
\hline 200 & 1 & 3 & 1 & 1 & 0 \\
400 & 2 & 8 & 3 & 2 & 10 \\
800 & 5 & 9 & 8 & 10 & 4 \\
1200 & 7 & 0 & 6 & 7 & 1 \\
1600 & 4 & 0 & 2 & 0 & 3 \\
2000 & 1 & 0 & 0 & 0 & 2 \\
$P$ & & & $<0.01$ & &
\end{tabular}

$\%$ level of

tolerance ${ }^{\dagger} \quad 60 \%(\mathrm{H}) 55 \%(\mathrm{~L}) \mathbf{4 0 \%}(\mathrm{H}) 35 \%(\mathrm{H}) \mathbf{7 5 \%}(\mathrm{H})$

$$
p^{\dagger}<0.05
$$

$p$ value is from Kurskal-Wallis testing the hypothesis that all Aspergillus isolates exhibited similar MIC values with all metals + Percentage of level of tolerance expressed as High tolerance (when the MIC are $1000 \mu \mathrm{g} \mathrm{ml}-1$ and more), Intermediate tolerance (when the MIC values are between 900 and 700 $\mu \mathrm{g} \mathrm{ml}^{-1}$ ) and Low tolerance (when MIC values are $600 \mu \mathrm{g}$ $\mathrm{ml}^{-1}$ and less)

$p^{+}$is the $p$ value of Mann-Whitney (U test) to compare the MIC values of the 20 Aspergillus isolates against $\mathrm{Cd}$ (low tolerance) and Co (high tolerance).

\section{DISCUSSION}

The physicochemical studies of the soil from three sites indicated no apparent change in the general soil characteristics. This demonstrate that long term application of wastewater has not yet resulted any significant change in major soil characteristics. Soil samples from contaminated (Site-A and Site-B) and control site (Site-C), have little variations in general characteristics of soil such as $\mathrm{pH}$, texture, and organic matter content, it is logical to assume that any increase in metal tolerant fungi in contaminated soil with

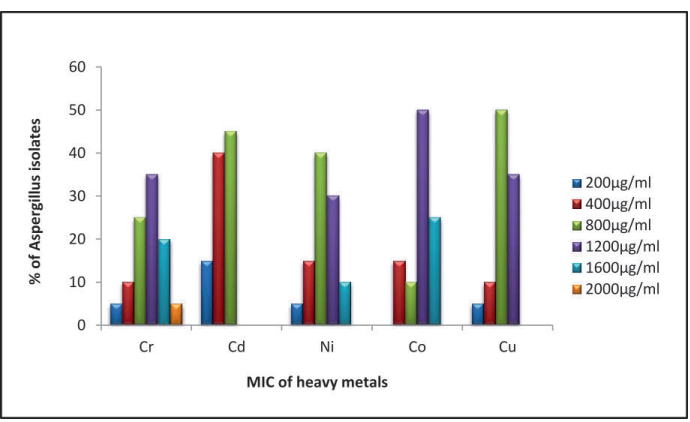

Fig. 4. Heavy metal tolerance (MIC) among 20 Aspergillus isolates.

wastewater can mainly be credited to the effects of application of wastewater containing heavy metals. The wastewaters from the same site were also previously reported to contain various heavy metals ${ }^{25}$ ). The content of heavy metals from both contaminated and uncontaminated soil varied significantly for $\mathrm{Co}^{++}, \mathrm{Ni}^{++}, \mathrm{Cr}^{6+}, \mathrm{Cd}^{++}$and $\mathrm{Cu}^{++}$. The data indicate that wastewater application has resulted heavy accumulation in soil. However, several abiotic factors are known to influence the speciation and fixation of metals, solubility, and metal -microbe interaction in soil ${ }^{4}$. For example, a decrease in $\mathrm{pH}$ in soil solution may increase the toxicity of metals towards microbes ${ }^{26}$. Similarly increase in organic matter may reduce the availability of metal and toxicity to microbes and plants. Though, the soil samples in the current study have shown an alkaline $\mathrm{pH}(7.8 \pm 0.2)$ and, thus indicating that soil $\mathrm{pH}$ has not contributed in toxicity of metal under soil condition.

Short term in vitro study on concentrationdependent toxicity of metals to soil bacterial populations have been demonstrated previously ${ }^{5}$.

The total viable plate counts of fungi from soil collected from both treated and control sites indicated that overall fungal dynamics are maintained in both groups of soil with no significant difference. This is probably due to the continuous exposure of metal-containing wastewater has resulted in the physiological adaptation in fungi to survive under stress conditions. In a long term study of wastewater application it was found that an increasing level of metal tolerance in Bradyrhizobium, and Rhizobium isolated from soil contaminated with oil refinery wastewater 27,28 . However, such study on soil fungal population is not available for comparison. 
In this study, culturable fungal species were enumerated on selective nutrient medium (SDA) supplemented with individual heavy metals. The significant decrease in CFUs count at elevated concentration $\left(400 \mathrm{\mu g} \mathrm{ml}^{-1}\right)$ was recorded.

The effect of heavy metal contamination on the number of culturable soil fungi as well as the diversity of fungal species varied $9,29,30,31,32$. Various mechanisms of metal tolerance among fungal communities are known, such as extracellular sequestration (binding to the cell wall) or intracellular binding to specific proteins ${ }^{10,33}$. Therefore, fungal population could exhibit great adaptation ability against stress conditions ${ }^{10,30,32}$ 33. However, it is difficult to compare the results of the current study with other published works due to the differences in the followed methods, environmental conditions, $\mathrm{pH}$, organic matter content, soil type, salt concentration, vegetation and contaminants, and their extent of pollution. The occurrence of metal tolerant fungi belonging to attest 18 genera in this study are comparable with the reports of other workers who have reported isolation of common genera, like Aspergillus, Penicillium etc as tolerant fungi from metal contaminated soil ${ }^{17,18,19}$.

The current study found that the increase in metal concentration from 100 to $400 \mu \mathrm{g} \mathrm{ml}^{-1}$ in the SDA medium resulted in a decrease in the diversity of fungal species compared to the fungal diversity observed in control plates. This decrease in diversity appears to be dependent on the type of metal itself and its concentration in the cultivation media. In all three sites soil samples similar effect on reduction in fungal diversity was observed at different metal concentration. However, $\mathrm{Co}, \mathrm{Cu}$, and $\mathrm{Ni}$ exerted more reduction compared to $\mathrm{Cd}$ and $\mathrm{Cr}$. Apparent differences in diversity of fungi developed on metal supplemented plates was evident from treated and control sites. However, to conclude such comparative study on fungal diversity differences from different soil sites it requires detailed investigation with more number of samples using both cultural and molecular based methods. Dirginciute- Volodkiene and Peciulyte (9) reported that elevated heavy metal contamination was shown to influence the fungal soil community structure; some indigenous soil fungal species (e.g. Absidia, Acremonium) were unable to grow after heavy metal exposure, while other species (e.g. Penicillium, Paecillomyces) grew abundantly after exposure to various concentrations of heavy metal. The difference in the diversity of fungi at different metal amended plates is probably due to their different level of intrinsic tolerance to these metals and toxicity differences of heavy metals.

Seventy-three fungal isolates randomly recovered, were subjected to determine the tolerance limits in terms of metal MIC values. High level of MIC value upto $2000 \mathrm{\mu g} \mathrm{ml}^{-1}$ was recorded against $\mathrm{Cr}^{6+}, \mathrm{Co}^{++}, \mathrm{Ni}^{++}$, and $\mathrm{Cu}^{++}$among one or more test fungal isolates. However, maximum tolerance against $\mathrm{Cd}^{++}$was upto $1600 \mu \mathrm{g} \mathrm{ml}^{-1}$.The data on MIC values have demonstrated the level of tolerance of fungi against individual metal between genera, species, and even the isolates of the same species. Similar observation was noted by Li et $a l .{ }^{29}$ and suggested that variations in metal tolerance in different taxa or within the same species may be attributed to different expressions of metal-tolerance genes. Among the 18 genera, Aspergillus was the most abundant species present in this study (20 isolates, $45.1 \%$ of fungal isolated). Aspergillus spp. have been widely reported for their great capacity in heavy metal tolerance in various geographical locations worldwide ${ }^{34,35,36,37,38}$. The Majority of the fungal isolates such as Penicillium, Cuvularia, Mycelia sterillia and Rhizopus, showed resistance to multiple metals, similar observations have been reported earlier ${ }^{30,32,38}$. These apparent multiple tolerances are probably expected due to physiological and genetic modifications and adaptation of these isolates due to the exposure with metals over a longer period. The fungal cell wall has distinctive properties to bind metals due to the negative charge on various functional groups $^{39}$.

Additionally efflux pump mechanisms in these isolates provide more advantages in multi-metal resistance ${ }^{2}$. Other multi-resistant mechanisms might include ion exchange and precipitation ${ }^{40}$. Diversity of metal tolerant fungi might have also been enriched due to the introduction of wastewater fungi in the field soil by irrigation. Therefore, the apparent differences between various taxa and within the same species in terms of their metal tolerance might be also due to the different levels of exposure to heavy metals. Variability in metal tolerance between different isolates of the same genus became more 
apparent when 20 distinct isolates of Aspergillus demonstrated variations in metal tolerance limits against one or more metals starting from 200 to $2000 \mathrm{\mu g} \mathrm{ml}^{-1}$.Aspergillus species have shown greater capacities of metal tolerance, as previously reported ${ }^{34-38}$. Aspergillus flavus was able to grow and tolerate in media contained heavy metal $\left(\mathrm{Cd}^{++}\right.$, $\mathrm{Cu}^{++}, \mathrm{Pb}^{++}$and $\mathrm{Zn}^{++}$) as well as its effective removal under halophilic conditions, which may be due to the ability of fungi to carry better metal biosorption under low water activity ${ }^{37}$. Tolerance of Aspergillus niger to lead $(\mathrm{Pb})$ was found by Tran et al. ${ }^{38}$ to be due to the secretion of oxalic acid that interacts with lead to form lead oxalate to lessen the $\mathrm{Pb}$ toxicity. Also, A. niger can build the new border of the cell wall to prevent the transportation of lead $(\mathrm{Pb})$ into hyphae. Besides, $A$. niger can still be active even at higher concentration of $\mathrm{Pb}$ due to the intracellular accumulation ${ }^{38}$. These findings indicate that Aspergillus species have shown greater capacities in metal tolerance and metal accumulation. It has been widely suggested that Aspergillus species might be very effective in bioremediation of metal contaminated soils (38). Aspergillus foetidus showed substantial tolerance to $\mathrm{Co}^{++}, \mathrm{Cr}^{6+}, \mathrm{Cu}^{++}, \mathrm{Ni}^{++}, \mathrm{Zn}^{++}$and other metal by the production of extracellular metabolites that are capable of absorbing and binding metals on the cell surface. A second mechanism was also observed by the same species by the intracellular binding of these metals to thiol-containing compounds for their detoxification that later be sequestrated into sub-cellular compartments of vacuoles ${ }^{34}$. Furthermore, Aspergillus species have shown metal tolerance under wide range of $\mathrm{pH}$ levels, for instance, $A$. flavus was reported to tolerate $\mathrm{Cu}$ and $\mathrm{Pb}$ under alkaline $\mathrm{pH}$ (8.0-9.0), whereas $A$. niger favored the acidic conditions $(\mathrm{pH} 4.0-5.4)^{35}$. Aspergillus species were also found to have heavy metal efflux pump system, which is one of the important primary mechanisms of metal tolerance in microorganisms ${ }^{2,41}$. It is revealed recently that extreme environmental conditions could exert changes in the DNA, that influence the structure of the transport proteins and the functions of enzymes responsible for metal tolerance, that lead to improve interactions with heavy metals to enhance metal efflux pump efficiency in Aspergillus flavus ${ }^{41}$. Further physiological and genetic studies beside advance molecular determination of fungal community are needed to develop heavy metal bioremediation technologies.

\section{CONCLUSIONS}

The present study indicated that long term release of wastewater containing heavy metal have resulted accumulation of certain metals in the soil. The fungal population of soil have adapted to metal contamination stress in soil by developing different levels of metal tolerance. However, the diversity of fungi might be adversely affected by elevated concentrations of toxic metals as recovery of soil fungi on metal amended plate decreases with increasing concentration. The common soil fungi have demostarted varied levels of metal tolerance to metals even in single genus/ species. However to conclude the impact of wastewater application on soil fungi diversity and activities long term monitoring on periodic analysis on free living, and endophytic like mycorrhizal fungi and their associated activities need to be investigated. Therefore, preventive treatments are needed to treat the wastewater properly before releasing to agricultural fields as it contains considerable amount of potentially toxic metals. Further, these metal tolerant fungal isolates may be further exploited for the removal or biosorption of toxic metals from wastewater.

\section{ACKNOWLEDGMENTS}

We thank Chairman, Department of Agricultural Microbiology, for providing departmental facilities to carry out this work. Mr. Mohd. Imran is also thankful to the UGC, New Delhi, for providing fellowship through AMU Aligarh.

\section{CONFLICT OF INTEREST} conflict of interest.

The authors declare that there is no

\section{AUTHORS' CONTRIBUTION}

All authors have made a substantial, direct, and intellectual contribution to the work and approve it for publication.

\section{FUNDING}

None. 


\section{DATA AVAILABILITY}

All datasets generated or analyzed during this study are included in the manuscript.

\section{ETHICS STATEMENT}

This article does not contain any studies with human participants or animals performed by any of the authors.

\section{REFERENCES}

1. Hayat S, Ahmad I, Pichtel J. Heavy Metal Contamination of Soil: Problems and Remedies.2005. Science Publishers, USA.

2. Osman GEH, Abulreesh HH, Elbanna K, Shaaban MR, Ahmad I. Recent progress in metal-microbe interactions: Prospects in bioremediation. J. Pure Appl. Microbiol.2019. 13: 13-25. https://doi.org/10.22207/ JPAM.13.1.02

3. Azi F, Odo MO, Okorie PA, Njoku HA, Oledimma NU, Nwobasi VN. Nwankwegu A.S. Microbial and heavy metal analysis of irrigation water and vegetables grown and consumed in Abakaliki metropolis. J. Pure Appl. Microbiol.2017. 11: 1855-1862. https://doi. org/10.22207/JPAM.11.4.26

4. Ahmad I, Hayat S, Ahmad S, Inam A, Samiullah. Influence of long term application of treated oil refinery effluent on soil health. In: Ahmad I, Hayat S, Pichtel J. (Eds), Heavy Metal Contamination of Soil: Problems and Remedies. 2005a, Science Publisher, Inc. USA, pp. 89-103.

5. Ahmad I, Hayat S, Ahmad A, Inam A, Samiullah. Effect of heavy metals on survival of certain groups of indigenous soil microbial population. J. Appl. Sci. Environ. Mgt.2005b.9: 115-121.

6. Ahmad MM, Ali A, Khan MA, Abdin MZ. Biomolecular characteristics of Aspergillus niger under cadmium metal stress. Environ.Process.2015.2:241-250. https:// doi.org/10.1007/s40710-014-0047-1

7. Giacomini SJ, Simon VLG, Aita C, Bastos LM, Weiler DA, Redin M. Carbonand nitrogen mineralization in soil combining sewage sludge and straw. Rev. Bras. Cien. Solo.2015.39: 1428-1435. https://doi. org/10.1590/01000683rbcs20140324

8. Chen L, Feng Q, Li C, Wei Y, Zhao Y, Feng Y, Zheng H, Li $\mathrm{F}$, Li H. Impacts of aquaculture wastewater irrigation on soil microbial functional diversity and community structure in arid regions. Sci. Rep.2017.7: 11193. https://doi.org/10.1038/s41598-017-11678-z

9. Dirginciute-Volodkiene V, Peciulyte D. Increased soil heavy metal concentrations affect the structure of soil fungus community. Agric. Conspec. Sci.2011.76: 27-33.

10. Liu S-H, Zeng G-M, Niu Q-Y, Liu Y, Zhou L, Jiang L-H, Tan X-F, Xu P, Zhang C, Cheng M. Bioremediation mechanisms of combined pollution of PAHs and heavy metals by bacteria and fungi: A mini review. Biores. Technol.2017.224: 25-33. https://doi.org/10.1016/j. biortech.2016.11.095

11. Shakya M, Sharma P, Meryem SS, Mahmood Q, Kumar A. Heavy metal removal from industrial wastewater using fungi: Uptake mechanisms and biochemical aspects. J. Environ. Eng.2016.142: C6015001 (18 pages). https://doi.org/10.1061/(ASCE)EE.19437870.0000983

12. Alguacil MDM, Torrecillas E, Torres P, Garcia-Orenes $\mathrm{F}$, Roldan A. Long-term effects of irrigation with waste water on soil AM fungi diversity and microbial activities: the implications for agro-ecosystem resilience. PLoS One.2012.7: e47680. https://doi. org/10.1371/journal.pone.0047680

13. Iftikhar S, Firdous S, Nadeem W, Erum S. Fungal diversity analysis in wastewater and agricultural soils irrigated with wastewater of Nullah Lai, Elixir Agricult. 2012. 52 : 11614-11620.

14. Rose KP, Devi R. Heavy metal tolerance and adaptability assessment of indigenous filamentous fungi isolated from industrial wastewater and sludge samples. Beni-suef University Jour. Basic and Appl. Sci. 2018.7: 688-694. https://doi.org/10.1016/j. bjbas.2018.08.001

15. Rousidou C, Papadopoulou K, Zervakis G, Singh BK, Ehaliotis C, Karpouzas DG. Repeated application of diluted olive mill wastewater induces changes in the structure of the soil microbial community. Eur. J. Soil Biol. 2010; 46: 34- 40. https://doi.org/10.1016/j. ejsobi.2009.10.004

16. Joo JH, Hussein KA. Heavy metal tolerance of fungi isolated from contaminated soil. Korean J. Soil Sci. Fert. 2012.45: 565-571. https://doi.org/10.7745/ KJSSF.2012.45.4.565

17. Anahid S., Yaghmaei S, Ghobadinejad Z. Heavy metal tolerance of fungi. Scientia Iranica. 2011.18:,502-508. https://doi.org/10.1016/j.scient.2011.05.015

18. Rasool A Iram S. Toxic effect of heavy metals on filamentous fungi isolated from contaminated soil of Kasur, Int. J. Sci. Eng. Res. 2014. 5: 400-407

19. Akhtar S, Mahmood-ul-Hassan M, Ahmad R, Suthor $\mathrm{V}$, Yasin M. Metal tolerance potential of filamentous fungi isolated from soils irrigated with untreated municipal. Soil Environ. 2013.32: 55-62,

20. Vanloon JC, Lichwa J.A study of the atomic absorption determination of some important heavy metals in fertilizers and domestic sewage plant sludges.Environ. Lett.1973.4: 1-8. https://doi. org/10.1080/00139307309435477

21. APHA. Standard Methods for the Examination of Water and Wastewater $23^{\text {rd }}$ ed. 2017.American Public Health Association, Washington, D.C.

22. Joseph CG, Gilman A. A Manual of Soil Fungi. 1967. IOWA State Publisher.

23. Zafar S, Aqil F, Ahmad I. Metal tolerance and biosorption potential of filamentous fungi isolated from metal contaminated agricultural soil. Biores.Technol.2007.98:2557-2561. https://doi. org/10.1016/j.biortech.2006.09.051

24. Allain-Boule N, Levesue CA, Martines C, Belanger RR, Tweddell RJ. Identification of Pythium species associated with cavity-spot lesions on carrots in eastern Quebec. Can. J. Plant Pathol. 2004. 26: 365370. https://doi.org/10.1080/07060660409507154

25. Malik A, Jaiswal R. Metal resistance in pseudomonas strains isolated from soil treated with industrial wastewater. World J. Microbiol. 
Biotechnol.2000.16:108-117.

26. Oliveira A, Pampulha ME. Effects of long term heavy metal contamination on soil microbial characteristics. J. Biosc. Bioeng.2006.102:157-161. https://doi. org/10.1263/jbb.102.157

27. Ansari SA. Hayat S, Ahmad I. Emergence of high level of metal resistance in the strains of Rhizobium sp. (Vigna). J. Microb. World.2001.3:49-54.

28. Ahmad I, Hayat S, Aqil Ahmad, Inam A, Samiullah. Metal and antibiotic resistance traits in Bradyrhizobium sp. (Cajanus) isolated from soil receiving oil refinery wastewater. World J. Microbiol.Biotechnol.2001.17:379-384. https://doi. org/10.1023/A:1016762613272

29. Li H-Y, Li D-W, He C-M, Zhou Z-P, Mei T, Xu H-M. Diversity and heavy metal tolerance of endophytic fungi from six dominant plant species in a $\mathrm{Pb}-\mathrm{Zn}$ mine wasteland in China. Fung.Ecol.2012.5: 309-315. https://doi. org/10.1016/j.funeco.2011.06.002

30. Mohammadian E, Ahari AB, Arzanlou M, Oustan S, Khazaei SH. Tolerance to heavy metals in filamentous fungi isolated from contaminated mining soils in the Zanjan Province, Iran. Chemosphere.2017.185: 290-296. https://doi.org/10.1016/j.chemosphere.2017.07.022

31. Oladipo OG, Awotoye OO, Olayinka A, Bezuidenhout CC, Maboeta M.S. Heavy metal tolerance traits of filamentous fungi isolated from gold gemstone mining sites. Braz. J. Microbiol.2018.49: 29-37. https://doi. org/10.1016/j.bjm.2017.06.003

32. Torres-Cruz T.J, Hesse C, Kuske CR, Porras-Alfaro A. Presence and distribution of heavy metal tolerant fungi in surface soils of a temperate pine forest. Appl. Soil Ecol.2018.131: 66-74. https://doi.org/10.1016/j. apsoil.2018.08.001

33. Anahid S, Yaghmaei S, Ghobadinejad Z. Heavy metal tolerance of fungi. Sci. Iran. C.2011.18: 502-508. https://doi.org/10.1016/j.scient.2011.05.015

34. Ge W, Zamri D, Mineyama H, Valix M. Bioaccumulation of heavy metals on adapted Aspergillus foetidus. Adsorption.2011.17: 901-910. https://doi. org/10.1007/s10450-011-9359-x

35. Iram S, Abrar S. Biosorption of copper and lead by heavy metal resistant fungal isolates. Int. J. Sci. Res. Pub.2015.5: 1-5.

36. De Sotto R, Monsanto RZ, Edora JL, Bautista RH, Bennett RM, Dedeles GR. Reduction of $\mathrm{Cr}$ (VI) using indigenous Aspergillus spp. isolated from heavy metal contaminated sites. Mycosphere.2015.6: 53-59. https://doi.org/10.5943/mycosphere/6/1/6

37. Bano A, Hussain J, Akbar A, Mehmood K, Anwar M, Hasni MS, Ullah S, Sajid S, Ali I. Biosorption of heavy metals by obligate halophilic fungi. Chemosphere.2018.199: 218-222. https://doi. org/10.1016/j.chemosphere.2018.02.043

38. Tian D, Jiang $Z$, Jiang $L$, Su $M$, Feng $Z$, Zhang $L$, Wang S, Li Z, Hu S. A new insight into lead (II) tolerance of environmental fungi based on a study of Aspergillus niger and Penicillium oxalicum. Environ. Microbiol.2018.21: 471-479. https://doi. org/10.1111/1462-2920.14478

39. Tiwari S, Lata C. Heavy metal stress, signaling, and tolerance due toplant-associated microbes: An overview. Front. Plant Sci.2018.9: Article 452. https:// doi.org/10.3389/fpls.2018.00452

40. Binsadiq ARH. Review: fungal absorption and tolerance of heavy metal. J. Remote Sens. GIS.2014.2: 68-71.

41. Jaiswar A, Varshney D, Adholeya A, Prasad P. Do environmentally induced DNA variations mediate adaptation in Aspergillus flavus exposed to chromium stress in tannery sludge? BMC Genom.2018.19: 868. https://doi.org/10.1186/s12864-018-5244-2 